Original Research

\title{
The Relationship between Partner Support and Interdialytic Weight Gain (IDWG) Hemodialysis Patient
}

\author{
Mundakir Mundakir, Nur Fadillah, Retno Sumara, Asri Asri and Yuanita Wulandari
}

Muhammadiyah University of Surabaya, Surabaya, Indonesia

\begin{abstract}
Introduction: Patients undergoing hemodialysis experience an influence in terms of the biological, psychological, social and spiritual problems that they encounter. In particular, there are biological aspects that affect weight gain between dialysis sessions. In terms of the psychological aspect, there is an influence on emotional vulnerability, such as anxiety, fear and despair. They need family support, especially as part of a couple. This study aimed to determine the relationship between partner support and IDWG in hemodialysis patients.
\end{abstract}

Methods: This study used a descriptive cross-sectional design. The population consisted of 60 hemodialyzed people. The sample was recruited using purposive sampling, resulting in 42 respondents who met the inclusion criteria. The study was conducted in a Private Hospital in Surabaya. The independent variable was partner support and the dependent variable was the IDWG in the hemodialysis patient. The data was collected through a questionnaire and it was analyzed using the Spearman test.

Results: The results show that there was a relationship between partner support and IDWG hemodialysis patients with $p=0.025(\alpha \leq 0.05)$.

Conclusion: Good partner support reduces the low IDWG in hemodialysis patients. Therefore, determining the level of family support especially that given by a partner of a IDWG hemodialysis patients will positively support better IDWG hemodialysis patients, thus preventing them from the potential side effects of IDWG such as hypotension, muscle cramps, shortness of breath and cardiovascular problems.

\section{ARTICLE HISTORY}

Received: Dec 19, 2019

Accepted: Jan 13, 2020

\section{KEYWORDS}

partner support; IDWG; hemodialysis

\section{CONTACT}

Mundakir Mundakir $\triangle$ mundakir.ners@fik.umsurabaya.ac.id $\equiv$ Muhammadiyah University of Surabaya, Surabaya, Indonesia

Cite this as: Mundakir, M., Fadillah, N., Sumara, R., Asri. A., \& Wulandari, Y. (2019). The Relationship between Partner Support and Interdialytic Weight Gain (IDWG) Hemodialysis Patient. Jurnal Ners, 14(2), 210-214. doi:http://dx.doi.org/10.20473/in.v14i2.10863

\section{INTRODUCTION}

One of the problems experienced by hemodialysis patients is weight gain between the two sessions of dialysis, which is called uncontrolled inter-dialysis weight gain (IDWG). Weight gain between the dialysis sessions is a manifestation of the amount of fluid intake between dialysis sessions. IDWG additions that are too high can have negative effects on the body such as hypotension, muscle cramps, difficulty breathing, and cardiovascular problems. IDWG $>4 \%$ increases the frequency of hospitalization and IDWG exceeding $5.7 \%$ increases the mortality of patients (Wong et al., 2017). In the NKF KDOQI Guidelines (2002), it is mentioned that the weight gain interdialysis should not exceed $4.8 \%$ of dry weight. This is because excessive ultrafiltration can give rise to problems in terms of hemodynamics and cardiovascular disorders (Kurniawati, 2012).

The research conducted by Istanti (2011) showed that social and family support as well as self-efficacy were related to two through to five factors that contributed to IDGW incidents. One of strategies that have been suggested to limit IDGW is behavioral interventions. This strategy was developed to improve the adherence of fluid restriction, the improvement of xerostomia and the use of lower dialysate sodium concentration (Bossola, Pepe, \& Vulpio, 2018). Excessive salt consumption will increase ECF osmolality, which stimulates thirst. Behavioral interventions are applied to increase the compliance with the fluid restrictions. This behavioral intervention uses an approach to increase motivation, knowledge and understanding in order to 
improve the level of obedient behavior towards fluid restrictions.

The phenomenon of reduced salivary flow or xerostomia in hemodialysis patients is caused by the atrophy and fibrosis of the salivary glands. Therefore, finding strategies to stimulate the salivary glands is a solution to improve xerostomia. The high concentration of sodium dialysate stimulates thirst in hemodialysis patients. This is because the sodium dialysate concentration reduces sodium loss. The feeling of thirst will make the patient drink excess water. In this situation, the role of the family is very important to succeed in the implementation of a behavioral intervention. The source of family support that was the most instrumental was that of a couple (husband, wife). This is because the interaction of the individual first and foremost is the nearest person, which is often a partner. The purpose of this study was to determine the relationship between the supports from the partners with the IDWG of the patients undergoing hemodialysis.

\section{MATERIALS AND METHODS}

The study was a descriptive correlation with a crosssectional approach. The population was all of the patients with Chronic Kidney Disease (CKD) undergoing routine hemodialysis in a private hospital in Surabaya in January 2018, which is as many as 60 people. The sampling technique was total sampling. The inclusion criteria were patients who had underwent hemodialysis > 3 months, who were undergoing regular hemodialysis 2 times a week, who had a life partner, who had a stable hemodynamic condition and who were willing to participate as respondents. The exclusion criteria were patients who passed through the hemodialysis schedule, and the patients who could not measure their own weight. The patients who passed through the hemodialysis schedule were excluded. It is because in this study, IDWG is defined as patient weight gain between two sessions of dialysis due to excess fluid / food volume. If the respondents came to the hemodialysis therapy more than two weeks after the previous schedule, then the data from the respondents might be effect the research results. We assume that the weight gain of the respondents who underwent hemodialysis every two weeks was different from that of the respondents who received hemodialysis that was more than two weeks apart. The respondents who were unable to stand on their own to measure their weight found the data collection process difficult. The samples obtained from this study totaled 42 respondents. The independent variable was support from the spouse and the dependent variable was IDWG.

This study used questionnaires to obtain the demographic and spousal support data. The Support Spouse Questionnaire was developed by Pratita (2012). This questionnaire consists of 17 questions which measure the 4 spousal support dimensions. The four dimensions of support provided by the spouse are the emotional dimension, valuation dimension, instrumental dimension, and informational dimension. The score of the spousal support questionnaire was calculated by calculating the cumulative number of the respondents' answer scores divided by the number of question items. The test results on the reliability and validity were obtained. In the end, the spouse-focused questionnaire concluded that there was good support $(>3-4)$, enough support (2-3), and poor support $(<2)$. Weight scales and a self-developed observational checklist were used to measure IDWG. The researchers collected the data by themselves. The data collection procedures carried out during the two periods of hemodialysis. The first period of the data collection was done with the questionnaire respondents focused on their demographics and the spousal support data. Then their weight was measured after the completion of hemodialysis and the results were documented on the observational checklist. In the second period (scheduled with the hemodialysis respondents) of the data collection, the respondents' weight was collected before the respondents underwent hemodialysis. Because the data had a normal distribution, we used the median score to create the level of IDGW. The IDWG level was mild, moderate and heavy. SPSS 25 statistical analysis was used to determine the characteristics of the demographic data of the respondents. Since, both of the data scales were continuous and the data had a normal distribution, the Pearson Product Moment test was selected in order to determine the relationship between the independent variables and the dependent variable.

This study passed the institutional review board of Muhammadiyah University of Surabaya. The research permit was issued by the Department of Education and Research of the hospital as the chosen research setting. The whole process of submission took one and half months.

\section{RESULTS}

The majority of the respondents in terms of gender were male $(64.3 \%)$ and a small percentage were female $(35.7 \%)$. The average age of the respondents was 50.74 years old with a standard deviation of 10.883. The youngest age was 27 years old and the oldest was 74 years old. Most of the respondents had a high school education (40.5\%) and a small percentage was un-educated $(4.8 \%)$. Most of the respondents were un-employed (45.2\%) and a small percentage were private officers (4.8\%) (Table 1).

Based on Table 2, The spousal support level was good for the majority (57.1\%) and only $11.9 \%$ experienced less support. The majority of the respondents who underwent hemodialysis had done so for more than 12 months (90.5\%) and a small portion had been undergoing hemodialysis for $\leq 12$ months (9.5\%). The mean IDGW value was 2.89 (95\% $\mathrm{CI}=2.74-3.04)$ while the mean value of spousal support was $2.45(95 \% \mathrm{CI}=2.21-2.64)$. The mean 
Table 1. The Respondent Characteristic Distribution by Demographic Data $(n=42)$

\begin{tabular}{|c|c|c|}
\hline Demographic Characteristics & $\mathbf{n}$ & $\%$ \\
\hline \multicolumn{3}{|l|}{ Gender } \\
\hline Male & 27 & 64.3 \\
\hline Female & 15 & 35.7 \\
\hline \multicolumn{3}{|l|}{ Age } \\
\hline 27-34 years old & 3 & 7.1 \\
\hline $35-42$ years old & 6 & 14.3 \\
\hline $43-50$ years old & 12 & 28.6 \\
\hline $51-58$ years old & 10 & 23.8 \\
\hline 59-66 years old & 9 & 21.4 \\
\hline $67-75$ years old & 2 & 4.8 \\
\hline \multicolumn{3}{|l|}{ Education background } \\
\hline Un-educated & 2 & 4.8 \\
\hline Elementary School & 6 & 14.3 \\
\hline Junior High School & 9 & 21.4 \\
\hline Senior High School & 17 & 40.5 \\
\hline Bachelor & 8 & 19.0 \\
\hline \multicolumn{3}{|l|}{ Occupational } \\
\hline Un-employed & 19 & 45.2 \\
\hline Public Service Officer & 3 & 7.1 \\
\hline Private Officer & 2 & 4.8 \\
\hline Entrepreneur & 13 & 31.0 \\
\hline Retired & 5 & 11.9 \\
\hline
\end{tabular}

value of the length of hemodialysis was 47.61 (95\% CI $=43.72-57.09$ ). This is based on the statistical Spearmen test result with a significant p-value of $0.025(\alpha \leq 0.05)$. Thus, $\mathrm{p}$ is smaller than $\alpha[0.025$ $<0.05]$ so therefore there is a relationship between the support of the spouses with the Interdialytic Weight Gain (IDWG) experienced by hemodialysis patients in Hospital Al-Irsyad Surabaya.

\section{DISCUSSION}

\section{Identification of the spousal support in the patients undergoing hemodialysis therapy}

The results showed that $57.1 \%$ of respondents have good life partner support and only $11.9 \%$ had less. It can be said that the majority of respondents in this study are supported in an optimal way. In the patients undergoing hemodialysis, indispensable support from their spouses is evidenced because the actions of hemodialysis are done for life. These actions can cause stress and boredom for the patients otherwise. Support from their spouse can increase a patient's life in relation to adherence. Juárez-Ramírez et al (2015) also stated that a greater level of social support mainly comes from partner-related compliance. It serves to reduce the adverse effects of stress and to help in the management of the disease.

The level of support provided by the spouses of the respondents in these studies can be influenced by religious factors, as the majority of the respondents' were Muslim (95.2\%). Islam teaches that in marriage (husband / wife), there must be mutual affectionate support and mutual help. There is a sense of responsibility as part of a pair where there is mutual support against any state experienced, including accepting the condition or disease suffered by the partner, and giving in to God. This is in accordance with the hadith of the Prophet Muhammad who said that the best man is the one who is the most kind to his family.

Supportive spouses will make for a more harmonious relationship and it can also increase the happiness felt because they will give their help voluntarily and on the basis of love to cure their ailing spouse. This was also supported by Pratita (2013) who explained that in a marriage, two people as one have a mutual sense of desire, unity, interdependence, mutual service, mutual encouragement and support. Prasetyawati et al (2012) identified that spousal support may come in one of four forms: emotional, appraisal, informational, and instrumental. Emotional support given to the couples in this study is in the form of encouragement in terms of the treatment, giving them the motivation to comply with the rules of eating / drinking and giving attention to their partner. Thus the hemodialysis patients feel less alone because of the people watching them.

According to Friedemann, Newman, Buckwalter, \& Montgomery (2014), support can be provided through the assessment of the positive expressions of couples, approval of the idea of support and the feeling that your partner can help with troubleshooting. Support ratings were given through the expression of praise when no medical progress was made, when overseeing the implementation of the rules of eating / drinking, and when they were either happy or angry if the respondent violated the rules related to eating / drinking as set by the doctor. Thus the respondents sought to maintain an 
Table 2. IDWG Relationship with Spousal Support and the Length of Hemodialysis ( $\mathrm{n}=42$ )

\begin{tabular}{|c|c|c|c|c|c|c|c|}
\hline Variables & $\mathbf{n}$ & $\%$ & Mean & SD & Min-Max & 95\% CI & $\mathbf{P}$ \\
\hline IDWG & & & 2.89 & 1.472 & $0-6.5$ & $2.74-3.04$ & \\
\hline Mild & 17 & $40.5 \%$ & & & & & \\
\hline Moderate & 22 & $52.4 \%$ & & & & & \\
\hline Heavy & 3 & $7.1 \%$ & & & & & 0.025 \\
\hline Spouse Support & & & 2.45 & 0.705 & $1-4$ & $2.21-2.64$ & \\
\hline Poor & 5 & 11.9 & & & & & \\
\hline Moderate & 13 & 31.0 & & & & & \\
\hline Good & 24 & 57.1 & & & & & \\
\hline Length of Hemodialysis & & & 47.61 & 32.70 & $4-126$ & $43.72-57.09$ & \\
\hline$\leq 12$ months & 4 & 9.5 & & & & & \\
\hline >12 months & 38 & 90.5 & & & & & \\
\hline
\end{tabular}

appropriate fluid intake because the doctor who recommended it was the one watching. Informational support refers to the guidance, advice or explanation related to how couples behave and how they try to find a way out of the problem. In this case, this is the regulation of body weight over time while on dialysis. Support is given in the form of advice given to the couples to encourage them to abide by the rules about drinking, including telling them about the consequences of excessive drinking, and informing them about all of the information passed on from the doctor or nurse to the respondent. This is so then the respondents understand the consequences if they break the rules of eating / drinking that are set.

Instrumental support is given in the form of practical and concrete help as needed. The support of this instrument is in the form of a couple who prepare their food / beverages together according to the rules set both in the home and at hospital. During the study, it can be observed that the respondents who underwent hemodialysis were facilitated in this by their life partner, such as by delivering the respondents to the hospital and even bringing in food and drinks according to the rules set by the doctor. Thus the results of the respondents support that the most couples are a form of instrumental support.

\section{Identification of IDWG in Hemodialysis Patients}

The results showed that the lowest IDWG respondents had a result of $0 \%$. The highest IDWG found was $33.3 \%$. This is contrary to other research which states that weight gain between the dialysis sessions of zero ml would not be possible (Yosi Suryarinilsih, 2010). IDWG is an increase in the volume of fluid that is manifested by an increase in body weight as the basis used to determine the amount of fluid intake during the inter-dialitic period. The patients were routinely measured in terms of weight before and after hemodialysis in order to determine the condition of the fluid in the patient's body. IDWG was calculated based on their dry weight after hemodialysis (Istanti, 2013). Weight gain due to too much fluid has become one of the prognoses of kidney failure, which affects survival time.

The greater the weight gain, the lower the level of patient safety (Kurniawati, 2012). Most of the respondents know the result of excess IDWG due to the information received from their doctors and nurses during hemodialysis. The respondents' knowledge about the consequences of excessive IDWG can be influenced by the respondents' education, which for 17 respondents (40.5\%) was that of high school level. According to Arnold (2008) and Suryarinilsih (2010), they said that the higher the level of education of a person, the better they tend to behave. This is because education is obtained in order to lay the foundations of understanding (comprehension) and behavior in a person. During the course of HD, patients with CKD are always given good insights by the doctors or nurses to encourage them to reduce their fluid intake. This is because this will have an impact on the patient's IDGW.

When at home, the respondents receive support from their spouse in the form of emotional support, appraisal, information and instrumental assistance so then the patients can better adhere to the drinking rules that must be followed. This encourages there to be no heavy IDWG. This is in line with the research conducted by Pratita (2012) who found that married couples can persuade or seduce their partners to encourage them to comply with some of the things that have been recommended by doctors including the eating and drinking rules. The results of these studies showed that the average HD duration experienced by the respondents ranged from 43.72 months to 57.09 months. The longer the patients underwent hemodialysis therapy for, the more knowledge they acquired. This allowed them to be more positive concerning their compliance with the liquid diet that can affect their IDWG. This is in line with the results of the study by Mustikasari (2017) which states that the duration of hemodialysis $(>1$ year) has an influence on knowledge, attitude and the patient's compliance with the restrictions concerning fluid intake. Each patient requires a different time period within which to improve their knowledge and attitude.

\section{The relationship between the support of their spouses with IDWG in hemodialysis patients in Hospital Al-Irsyad Surabaya}

The relationship between IDGW and spousal support in the Hemodialysis Unit produced a p-value of significance of 0.025 with $\alpha \leq 0.05$. The obtained $p$ is smaller than $\alpha[0.025<0.05]$, thus supporting the hypothesis maintained by the researchers that there is a relationship between the support of the spouses 
and IDWG in hemodialysis patients in Hospital AlIrsyad Surabaya. The longest period of time in terms of the respondents undergoing hemodialysis was 126 months while the shortest was 4 months. According to the investigators, the longer that the patients undergo hemodialysis for and the more that the patients are obedient in terms of undergoing hemodialysis, the more that they increasingly recognize their own bodies when it feels uncomfortable. Istanti (2011) states that one of the causes of weight gain is fluid intake. The respondents initially did not know about the causes of IDWG and this condition might have an impact due to their lack of knowledge.

The lack of knowledge of the respondent was caused by only a small proportion of respondents having a college-level education (8 respondents; $19 \%$ ). The remaining respondents' education level was below that. This is in line with the research results by Suryarinilsih (2010) which state that the higher a person's education level, the better their level of knowledge when it comes to seeking treatment and care.

The analysis in this study showed that most of the respondents were aged 43-50 years old, totaling 12 respondents $(28.6 \%)$. The age of the respondents is among those who are still very eager to seek treatment to improve their health. Age could also affect the compliance of the respondents when conducting hemodialysis and refer to keeping the weight gain between dialysis sessions at a level that is not too heavy. Based on these results, the majority of the respondents have the support of a life partner (24 respondents; 57.1\%). Delianty (2015) states that support from their life partner is the effort made by the married couple mentally, physically, and socially.

According to researchers, the spouse as well as those closest to the respondents serve as a support system for their partner. They noticed that the people who are supportive are always ready to provide assistance if needed, either in the form of thoughts when making the decision to undergo hemodialysis or providing the motivation to want to comply with the drinking rules that must be followed for the convenience of their partner. This is in line with the research conducted by Pratita (2012) showing that spousal support can improve patient compliance in terms of the therapy offered for chronic diseases, which in this case is hemodialysis and problems. Spousal support during the hemodialysis process is essential in order to maintain and improve the quality of life of the patient partner as well as to reduce the risk of health problems such as hypotension, muscle cramps, shortness of breath, and cardiovascular problems.

\section{CONCLUSION}

There is a significant relationship between the support given by the spouse and IDWG in hemodialysis patients. Good partner support reduces the IDWG in hemodialysis patients. Therefore, determining the level of family support, especially that given by the partner of the IDWG hemodialysis patients, will positively support a better level of IDWG. This prevents them from experiencing the potential negative side effects of IDWG such as hypotension, muscle cramps, shortness of breath, and cardiovascular problems. For further research to be referenced and developed in relation to conducting further research, it should be focused on the factors that affect the support of the spouses given to the patients on hemodialysis.

\section{REFERENCES}

Arnold, T. (2008). Predicting Fluid Adherence in Hemodialysis Patients via the IllnessPerception Questionaire - Revided. Counseling and Psychological Services Dissertations.

Bossola, M., Pepe, G., \& Vulpio, C. (2018, September 1). The Frustrating Attempt to Limit the Interdialytic Weight Gain in Patients on Chronic Hemodialysis: New Insights Into an Old Problem. Journal of Renal Nutrition, Vol. 28, pp. 293-301. https://doi.org/10.1053/j.jrn.2018.01.015

Delianty, Anggita Puspita. (2015). Hubungan Dukungan Pasangan Terhadap Kepatuhan Diet pada Penderita Diabetes Melitus Tipe 2 di Wilayah Kerja Puskesmas Munjul.

Friedemann, M. L., Newman, F. L., Buckwalter, K. C., \& Montgomery, R. J. V. (2014). Resource need and use of multiethnic caregivers of elders in their homes. Journal of Advanced Nursing, 70(3), 662673. https://doi.org/10.1111/jan.12230

Istanti, Yuni Permatasari. (2011). Faktor-Faktor yang Berkontribusi terhadap Interdialytic Weight Gains pada Pasien Chronic Kidney Diseases yang Menjalani Hemodialisis. Jurnal Kedokteran dan Kesehatan.

Istanti, Yuni Permatasari. (2013). Hubungan Antara Masukan Cairan Dengan Interdialytic Weight Gains (Idwg) Pada Pasien Chronic Kidney Diseases Di Unit Hemodialisis Rs Pku Muhammadiyah Yogyakarta I Semantic Scholar.

Kurniawati, Yosy. (2012). Hubungan Antara Dukungan Sosial Dengan Stres Pada Mahasiswa Fakultas Ekonomi Universitas Negeri Jakarta I Kumpulan Contoh Laporan Evaluasi.

Mustikasari, I. (2017). Faktor-Faktor Yang Mempengaruhi Nilai Interdialytic Weight Gain Pasien Hemodialisa Di Rsud Panembahan Senopati Bantul. Jurnal Kesehatan, 15(1), 78-86. https://doi.org/10.30787/gaster.v15i1.139

Pratita, Nurina Dewi. (2012). Hubungan Dukungan Pasangan dan Health Locus of Control dengan Kepatuhan dalam Menjalani Proses Pengobatan pada Penderita Diabetes Mellitus Tipe-2 - Neliti.

Suryarinilsih, Yosi. (2010). Hubungan Penambahan Berat Badan Antara Dua Waktu Dialisis Dengan Kualitas Hidup Pasien Hemodialisis Di Rumah Sakit Dr. M. Djamil Padang Tesis . 